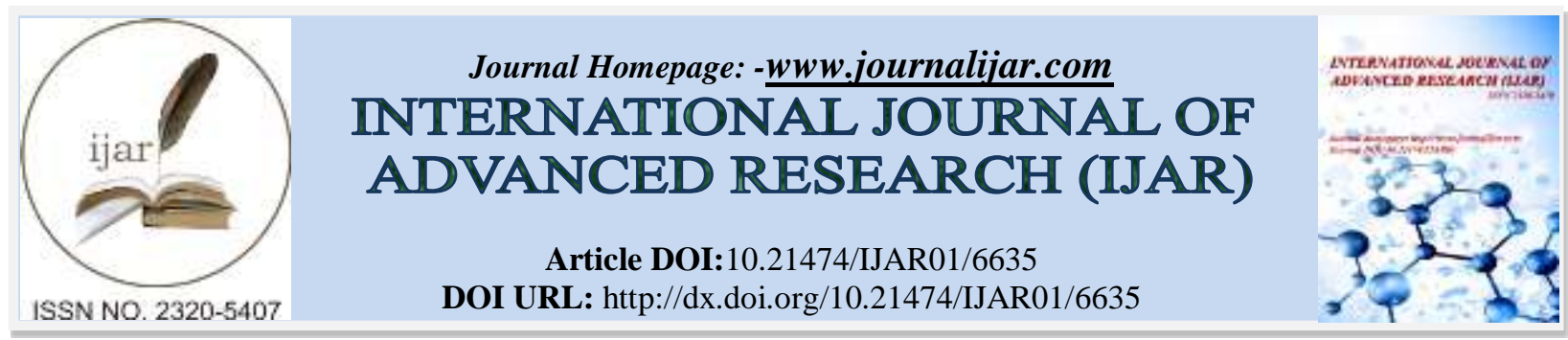

RESEARCH ARTICLE

\title{
ANALYSIS OF MICROBIOLOGICAL CONTAMINATION IN AQUIFERS, IN THE URBAN REGION OF OBLIGADO AND HOHENAU - PARAGUAY.
}

\section{Alicia Raquel Eisenkölbl Closs ${ }^{1}$, Estelvina Rodríguez Portillo ${ }^{2}$, Rafaela Laino ${ }^{3}$ and Antonio Aníbal Benítez Cañiza ${ }^{4}$.}

1. Postgraduate School, National University of Itapúa, Encarnación, Paraguay.

2. School of Science and Technology, National University of Itapúa, Encarnación, Paraguay.

3. Chaco Americano Research Center, Manuel Gondra Foundation.

4. Catholic University - School of Agricultural Sciences.

\section{Manuscript Info}

(.........................

Manuscript History

Received: 25 December 2017

Final Accepted: 27 January 2018

Published: February 2018

Keywords:-

Drinking Water, Water Quality, Total Coliforms, Underground Water, Water Supply

\section{Abstract}

In Paraguay, $85 \%$ of homes have water supply from enhanced sources, $63 \%$ are delivered by a distribution system. Likewise, $79 \%$ of homes have sanitary drains and $11 \%$ are connected to an effluent treatment system (Secretaría Técnica de Planificación del Desarrollo Económico y Social, 2015), this condition hints to superficial pollution problems as well as underground water. The Capiibary Stream watershed, situated in the Department of Itapúa, Paraguay and established on the Guarani Aquifer System (SAG, in Spanish), aquifers exploited by deep wells where the presence of fecal coliform is found in $60 \%$ of sampled wells (Protección y Manejo de Aguas Subterráneas en Paraguay PAS-PY, 2012). The study calculated variations in total coliforms in groundwater watershed detected in the center of Obligado and Hohenau, the analysis of groundwater property was based on data from 59 water samples taken over a 10-year period (2006-2016) in 17 deep wells, variations of total coliforms were estimated. For the statistical processing, the analysis of variance and contrast of means (Duncan test) with margin of error 5\% were performed. It was determined the variations of the overall coliforms in the study period 2006 to 2016, the presence of total coliforms topped the maximum acceptable threshold. Similarly, deep wells were detected in Obligado, whose standards extended up to 998 CFU / 100ml. Lastly, the results were contrasted with World Health Organization (WHO, 2006) parameters and the Official Paraguayan Standards ERSSAN (ERSSAN, 2017) Law Nº. 1614/2000.

Copy Right, IJAR, 2018,. All rights reserved.

\section{Introduction:-}

Global groundwater extraction increased from $312 \mathrm{~km}^{3} /$ year in the 1960 s to $743 \mathrm{~km}^{3} /$ year in 2000 . Nearly $70 \%$ of the water extracted is used for farming, the remaining 30\% corresponds to human consumption. Also, half of drinking water in urban regions comes from groundwater (Wada et al., 2010). 
Some viral and bacterial pathogens existing in human and animal waste contaminate groundwater and they are harmful to human health. In 2012, it was estimated that more than 500,000 diarrhea deaths were caused by microbiologically polluted water (Prüss-Ustün, 2014). Consistently, 50\% of the world's population meets their primary requirements from contaminated groundwater at some point (Macler \& Merkle, 2000).

World Health Organizations recommends that water intended for human consumption not to contain total coliforms ( $0 \mathrm{CFU} / \mathrm{ml})$. Notably, $61 \%$ of all countries in the world consider this parameter as a foundation for regulations related to the provision of water for human consumption, including Canada, USA, Costa Rica, El Salvador, Bolivia, Brazil, Peru and Uruguay. Whereas 39\% of the world's countries allow values higher than zero, for example, in Chile, Colombia and Ecuador, they admit up to $1 \mathrm{CFU} / \mathrm{ml}$, as well as in Mexico, Ecuador, Honduras, Paraguay and Nicaragua the range is between 2 to $4 \mathrm{CFU} / \mathrm{ml}$ of total coliforms.

In Paraguay, according to information published by the Permanent Household Survey (EPH) 2008, 68.4\% of homes had access to a household connection to drinking water, whereas the rest of the population is self-supplied basically through wells with or without pumping equipment, artesian well or additional resources. In urban areas, drinking water provision through network connection was of $79.8 \%$, but just $14 \%$ of urban households had access to sewage system, furthermore only half of these homes had some kind of water treatment. Unfortunately, indigenous communities belonging to different ethnic groups have the lowest levels of access to public services: scarcely, 5.9\% have a connection to a clean water system and just 3.3\% to sewerage or other effluent treatment system. At the national level, the growth of drinking water coverage has improved substantially since the mid-1990s. While in 1995 only $39.1 \%$ of the population had a home connection, in 2007 it reached a coverage of just over two thirds of the total population $(69.3 \%)$. However, in 1995 only $39.1 \%$ of the people had water connection at home, in 2007 it reached a coverage of about two thirds of the entire population (69.3\%). Throughout the same period, coverage in the rural area experienced the biggest increase in water connection at home. As outlined in Paraguay's Strategic Water and Sanitation Sector Strategic Plan, the investment requirements to meet the Millennium Development Goals (MDGs) for the 2008-2015 period is US \$ 733 million; where 88\% of these are situated in urban areas and just 12\% in rural areas cited by (Spanish Agency for International Development Cooperation, AECID, 2017).

The Capiíbary stream watershed is found within the Guarani Aquifer System (SAG), in the Department of Itapúa, Paraguay; which represents a significant cross-border underground water body shared by Argentina, Brazil, Paraguay and Uruguay; where the aquifers (Alto Paraná formation and Misiones formation) serve as water reservoirs and supplies. They are exploited by deep wells to supply the urban area of Obligado and Hohenau.

As background on groundwater quality in Paraguay, which is part of the study area and particularly in the Arroyo Capiibary watershed, it can be mentioned studies carried on in SAG, project under the Environmental Protection and Sustainable Development of the Guarani Aquifer System (PSAG) that was launched in March 2003 and completed in January 2009 (PSAG, 2009). SAGPY Project for Environmental Protection and Sustainable Development of the Guarani Aquifer System (SAGPY, 2009) and PAS-PY. Project "Sustainable Management and Protection of Groundwater in Paraguay" (PAS-PY, 2012), where microbiological studies have discovered an alarming contamination of fecal coliforms in more than $60 \%$ of wells sampled under the PAS-PY project (2012), particularly in urban areas of some major municipalities that form make up the Capiibary stream watershed, including urban areas of Obligado and Hohenau. This situation is constant in different areas of Paraguay, a condition that is due to the deficiency of a sewerage system and effluent treatment plants as well as latrines and blind wells being the main (direct) human supply water wells sources of pollution and this is directly related to the lack of protection boundaries for deep artesian wells (PAS-PY, 2012).

The presence of total coliforms arises concern since the whole surface of the Capiíbary stream watershed is situated on the Guaraní Aquifer System (SAG). Typically, groundwater does not contain microbiological pollutants such as Escherichia coli and fecal as well as total coliform, excepting it has been contaminated by percolation from superficial water or sewage connections. Frequently, bacterial contamination in groundwater is due to deficient well construction, inadequate well maintenance as well as the influences of the aquifer vulnerability.

The purpose of this study was to calculate the variation of the total coliform content in Hohenau and Obligado urban areas groundwater during the period of 2006-2016. 


\section{Material and Methods:-}

The study was performed in two districts in the Department of Itapúa in Paraguay, the district of Obligado in the Abbeg stream watershed that is situated at the coordinates: longitude 55 40'5.97"and latitude $27^{\circ} 06^{\prime} 29.60$ "; and the unnamed stream watershed in the district of Hohenau within the coordinates: longitude $55^{\circ} 35^{\prime} 58.89^{\prime \prime}$ and latitude $27^{\circ} 04^{\prime} 36.81^{\prime \prime}$ according to the geographical projections (Figure 1).

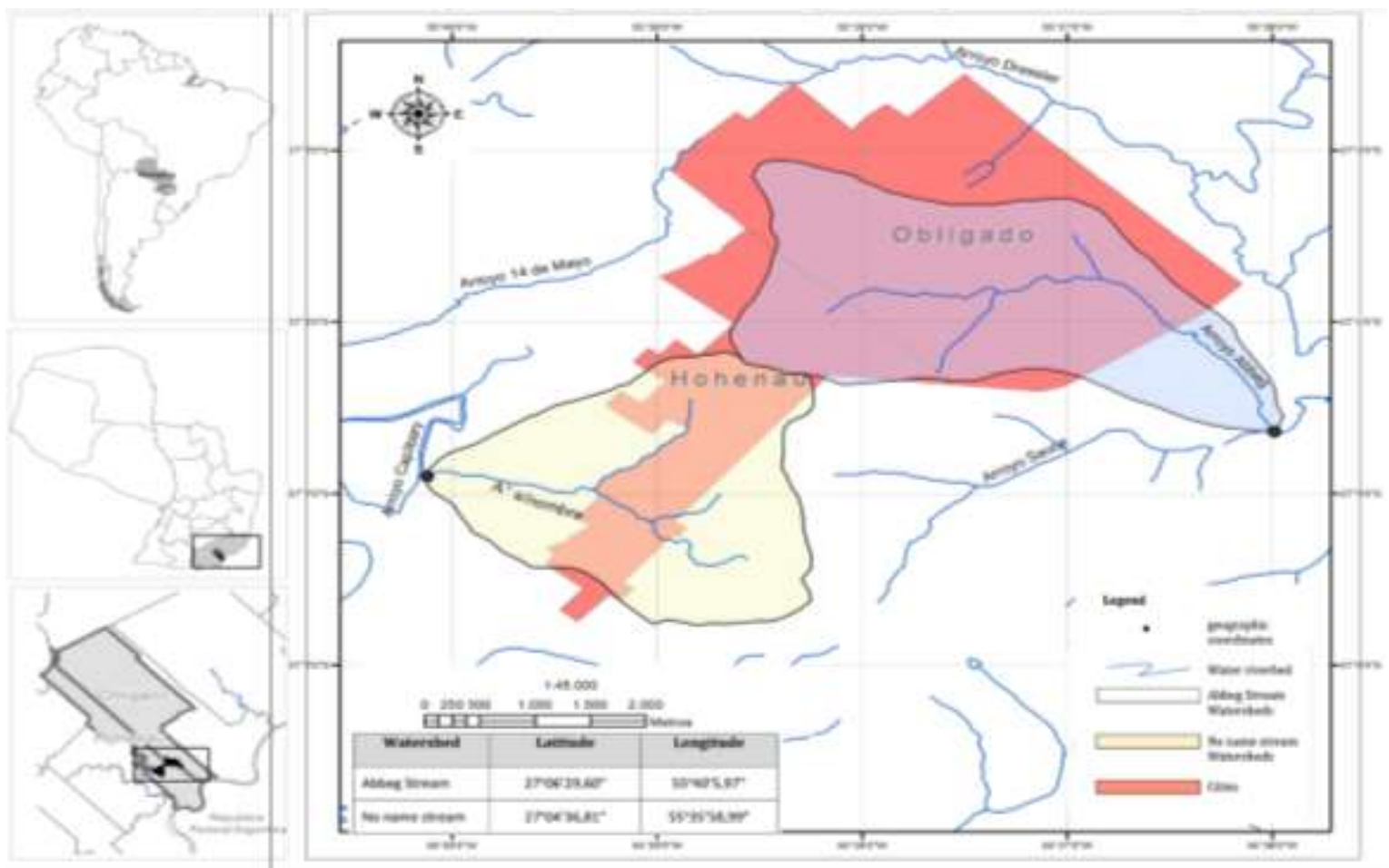

Figure 1:- Location of the research area. Paraguay, department of Itapúa, districts of Hohenau and Obligado, geographic coordinates of the watershed capacity in study.

Most of the urban center of Obligado is situated on the $\mathrm{O}$ watershed, it has an area of 741.39 ha and its main channel (called Abbeg stream) has a length of $4849.60 \mathrm{~m}$, see Figure 2; and a great part of the urban center of Hohenau is located on the $\mathrm{H}$ watershed that has an area of 598 ha and the length of its main channel is 3217.18 meters, see figure 3 .

The region considered is characterized by extraordinary water wealth in terms of quality, quantity and depth of groundwater since it is located on the Guarani Aquifer (Misiones formation) (Faculty of Science and Technology, 2010). This formation contains sedimentary rocks sandstone that store large volumes of water in its pore spaces (PAS-PY, 2012).

Different soil types (USDA Soil Taxonomy) are developed in the area of study, predominantly Ult isol 10 soils in the upper and middle parts of the watershed, and at a lower level ULTISOL 2 in the lower watershed. The ULTISOL 10 is given on basaltic rock and to a smaller degree on sandstones, but constantly on th appropriate slopes with drainage surface. Soils are classified as II, III and V, with a dominance of class III: slopes from 8 to $15 \%$, efficient soil depth 75-100 cm, drainage and quick penetrability (MAG, 1995).

\section{Data collection:-}

Data from deep wells gathered under the SAG 2009, PSAG-PY 2009 and PAS-PY 2012 projects were used in this project, and the information was accomplished (until 2016) through interviews with key stakeholders in charge of water supply to the population where the research was carried out.

Wells were coded for better data management and statistical calculation thereof. Seventeen wells situated on the study area were chosen and 59 water samples were evaluated (Figures 2 and 3). 


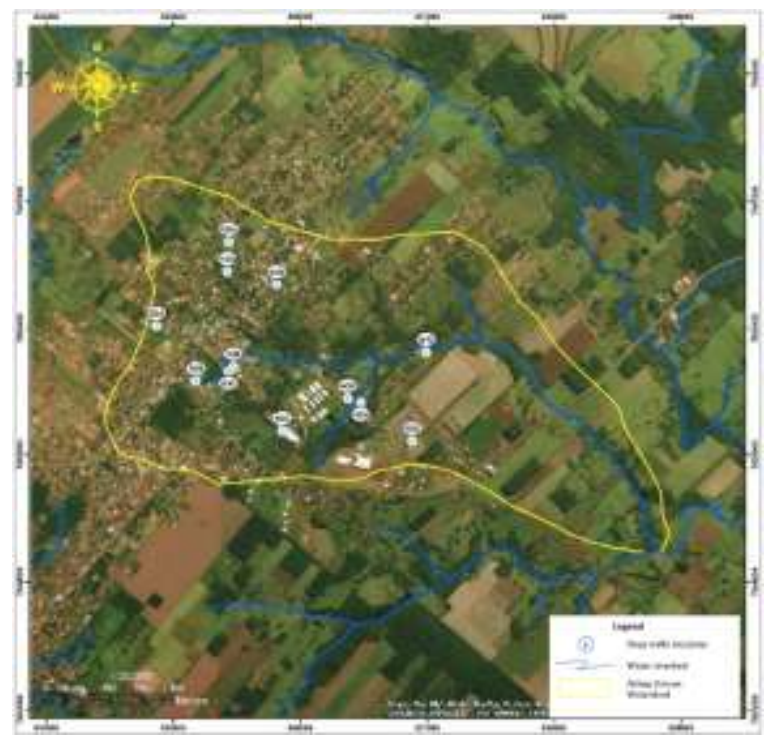

Figure 2:- Position of wells in "O" Small Watershed,

There were 11 wells that were coded, the nomenclature to identify them is as follow $1 \mathrm{OC}$, 2OC, 3OB, 4OB, 5OB, 6OB, 7OB, 8OA, 9OA, 10OA, 11OA (letter "O" for the Abbeg stream small watershed, the numbers from 1 to 11 correspond to the order number and the letters $\mathrm{ABC}$ source material) and the location of the treatment plant is identified with the nomenclature. WT2

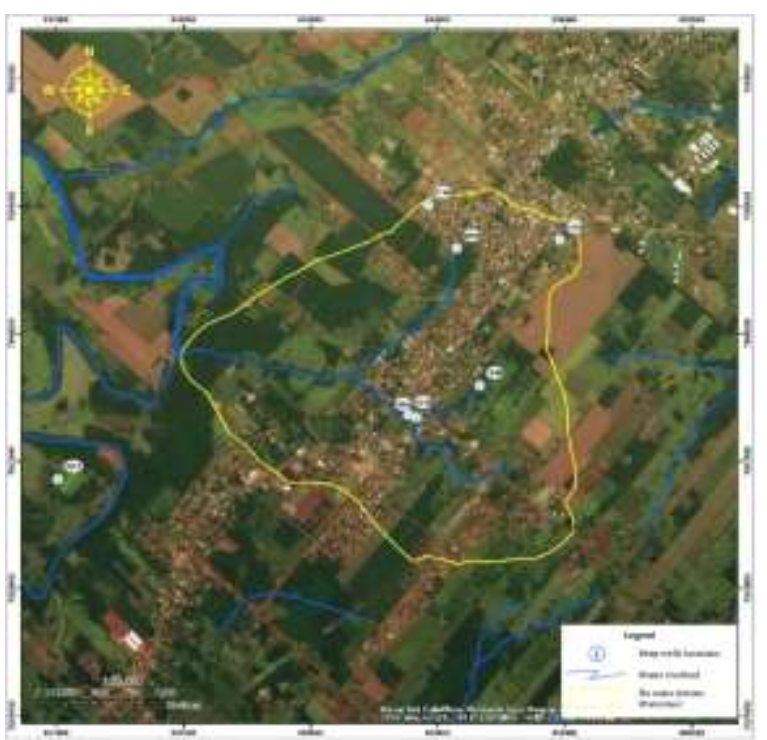

Figure 3:- Position of wells in " $\mathrm{H}$ " Small Watershed, six were the wells that were coded, the nomenclature to identify them is as follow $12 \mathrm{HB}, 13 \mathrm{HB}, 14 \mathrm{HB}$,

$15 \mathrm{HB}, 16 \mathrm{HB}, 17 \mathrm{HB}$ (letter $\mathrm{H}$ for the small watershed of the stream without name, the numbers 12 to 17 corresponds to order number and source material B), and the location of the treatment plant is identified with the nomenclature. WT1

It was analyzed data collected between 2006 and 2016, excluding years 2007 and 2011 period when there was not water quality analysis. Consequently, the period of study is 9 years. These Wells are controlled by private sectors and Sanitation Boards.

The average annual and cyclical rainfall throughout the analysis period was $1711.7 \mathrm{~mm}$ according to data from two meteorological stations located in the area of study, see Table 1. Rainfall data during the study period (2006 to 2016) can be seen in Figure 5, this information was gathered at the Federation of Production Cooperatives Ltda. website (FECOPROD, 2017), this station is $25 \mathrm{~km}$ away in straightforward line from the study area, additional source employed was METEORED from the city of Posadas, Misiones, Argentina, this station is in a straight line $48 \mathrm{~km}$ away from the area of study. (METEORED, 2017)

Table 1:- Seasonal rainfall during 2006-2016.

\begin{tabular}{|l|l|l|l|l|l|l|l|l|l|l|}
\hline \multirow{2}{*}{ Seasons } & $\mathbf{2 0 0 6}$ & $\mathbf{2 0 0 8}$ & $\mathbf{2 0 0 9}$ & $\mathbf{2 0 1 0}$ & $\mathbf{2 0 1 2}$ & $\mathbf{2 0 1 3}$ & $\mathbf{2 0 1 4}$ & $\mathbf{2 0 1 5}$ & $\mathbf{2 0 1 6}$ & Total \\
\cline { 2 - 11 } & Precipitatios in millimeters \\
\hline Autum & 257.3 & 514.7 & 306.4 & 440.2 & 371.1 & 404 & 609.2 & 410.8 & 223.4 & $\mathbf{3 5 3 7 . 1}$ \\
\hline Winter & 323.4 & 256.7 & 591.7 & 35.6 & 183.2 & 205 & 427.8 & 269.2 & 241 & $\mathbf{2 8 5 5 . 6}$ \\
\hline Summer & 284.5 & 207.4 & 325.3 & 272 & 190.4 & 464.2 & 507.8 & 431.6 & 518.4 & $\mathbf{3 2 0 1 . 6}$ \\
\hline Spring & 775.2 & 704.7 & 599.4 & 517 & $928, .5$ & 372.6 & 528.4 & 878.2 & 507.6 & $\mathbf{5 8 1 1 . 6}$ \\
\hline & $\mathbf{1 6 4 0 . 4}$ & $\mathbf{1 6 8 3 . 5}$ & $\mathbf{1 8 2 2 . 8}$ & $\mathbf{1 5 8 6 . 8}$ & $\mathbf{1 6 7 3 . 2}$ & $\mathbf{1 4 4 5 . 8}$ & $\mathbf{2 0 7 3 . 2}$ & $\mathbf{1 9 8 9 . 8}$ & $\mathbf{1 4 9 0 . 4}$ & $\mathbf{1 7 1 1 . 7}$ \\
\hline
\end{tabular}

Source: (meteored, 2017), (fecoprod, 2017). Seasonal rainfall during the period 2006 to 2016. 


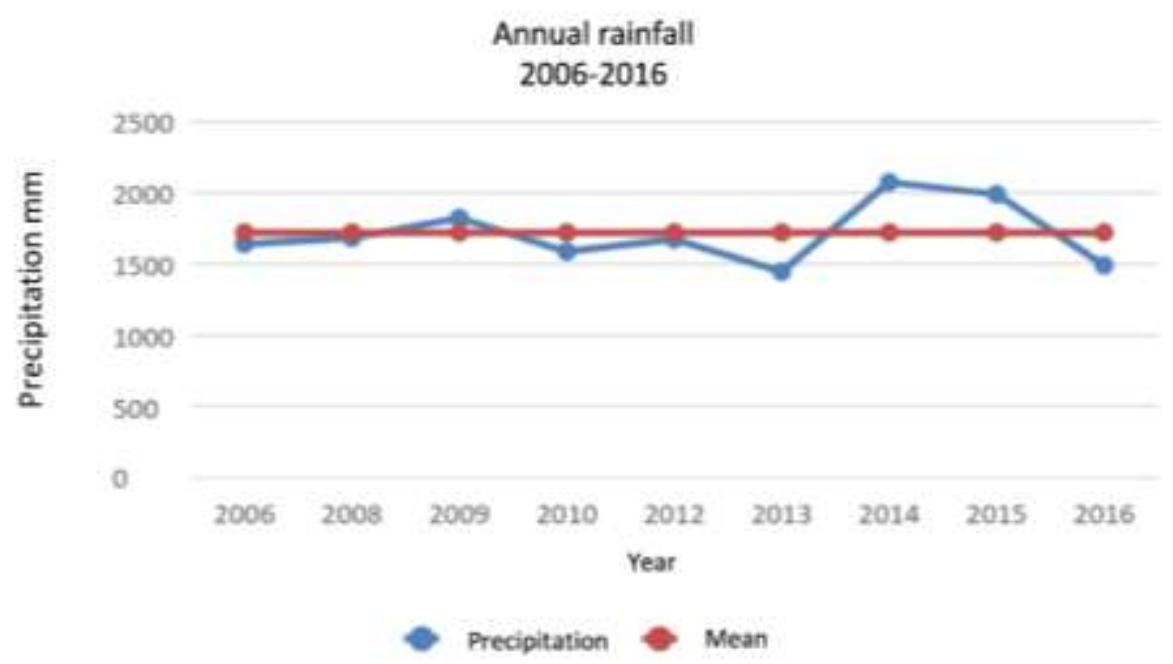

Figure 4:- Annual rainfall distribution (2006-2016).

Source: (METEORED, 2017), (FECOPROD, 2017). Average of annual rainfall, in the graph it is shown the fluctuation of precipitation over time during the period 2006 - 2016.

\section{Statistical Analysis:-}

To identify significant differences between variables, it was performed analysis of variance as well as contrast of means, likewise, Duncan test was applied at 5\% significance using the statistical program Infostat (2017p Version) (Di Rienzo, et al, 2017). It is important to mention that wells with a single data have been discarded since they produce a very marked statistical distribution.

For the analysis of the variable presence of total coliforms per well, wells with only one data have been discarded due to the fact that it generates a very marked statistical dispersion.

The outcomes were compared with levels established in the environmental guidelines related to the quality of water for human consumption in accordance with the World Health Organization (WHO, 2006) and the Official Paraguayan Standards ERSSAN (ERSSAN, 2017), to confirm the decline of water quality.

\section{Results:-}

Total coliforms

\section{Presence of total coliforms per well:-}

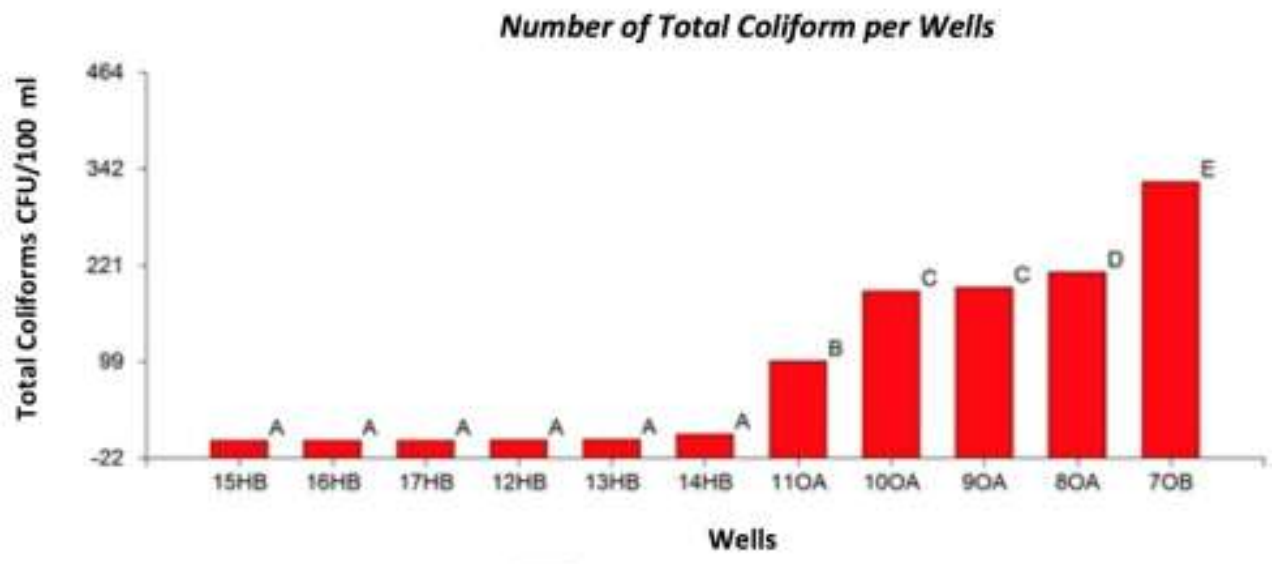

Total Coliforms CFU/100 ml 
Figure 5:- Microbiological water quality, distribution of total coliforms in wells spread in the area of study. The nomenclature indicates that the $\mathrm{O}$ codings belongs to the Abbeg stream small watershed and $\mathrm{H}$ coding corresponds to the unnamed stream small watershed, which connects to the wells of Hohenau water provider. Letters A and B match with the geological formation codification (A: sandstone, B: Basalt).

The Duncan test average contrast revealed a statistically significant difference between wells B formation: basalt, and wells A formation: sandstone, which suggests that the basalt formation wells are statistically similar to each other, except for well 70B that reveals a very significant statistical difference.

\section{Distribution of total coliforms along the period of study:-}

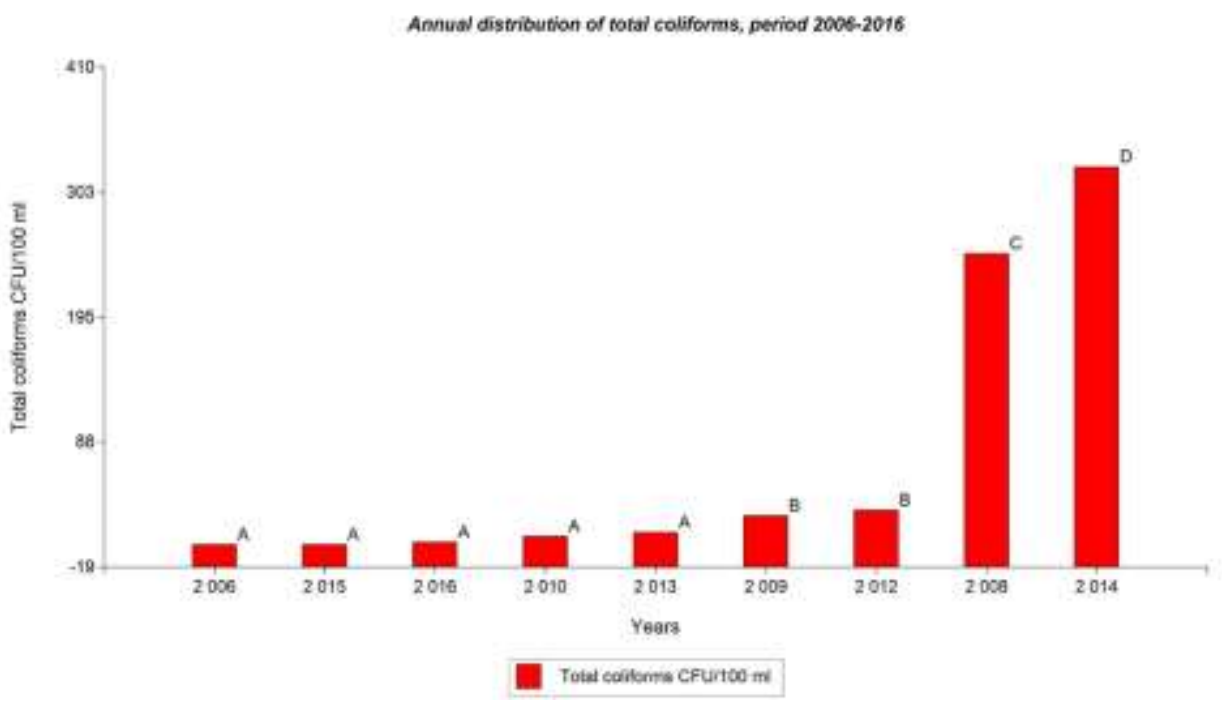

Figure 6:- Annual distribution of total coliforms, 2006-2016.

In Figure 6, it is shown the presence of total coliforms that was detected in waters of the wells examined. The highest concentrations of total coliforms were documented in 2014, these values varied from 302 to 410 CFU/100ml, followed by 2008 when they were between 195 and 302 CFU/100ml of total coliforms.

The excessive incidence of total coliforms in 2014 and 2008 may be associated to excessive rain, these rains may influence permeation or drag sewage, it can be affirmed that in 2014 period of greatest precipitation when the study was carried out, samples were acquired in autumn (season with the highest rainfall record), also considering the year 2008, it was documented a high number of total coliforms, nonetheless that year rains were below the average during the period of study, see figure 4 , being the season of highest rainfall during the year.

In 2015, the concentrations of total coliforms were lower, although it was a year of great rainfall, close to 2014 record, however in this particular year samples were taken in summer and winter (period of lower rains recording), so it is given a lower total coliforms registration. 


\section{Distribution of Total Coliforms be season:-}

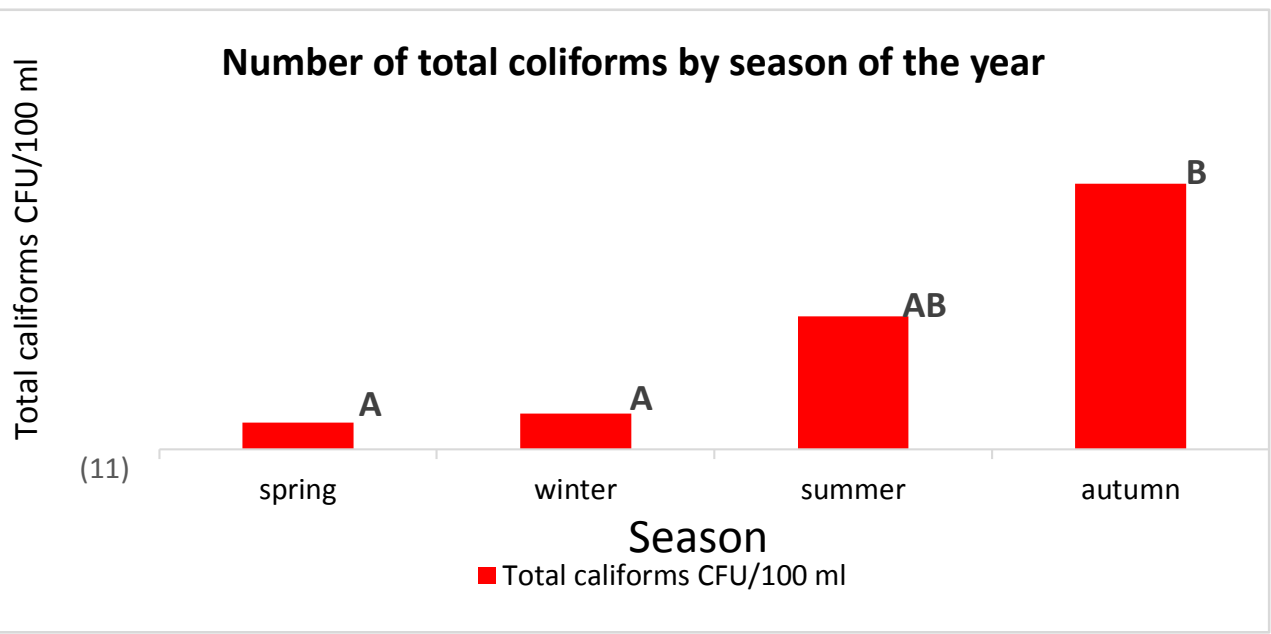

Figure 7:- Presence of total coliforms according to seasons of the year.

The number of total coliforms as shown in Figure 7, happens in greater quantity in the summer and autumn, in table 1 , the seasons with the most abundant rainfall during the period of study are correspondingly spring, summer and autumn. See table 1.

\section{Discussion:-}

Once the historical data collected from 2006 to 20016 was analyzed, it can be affirmed that groundwater is contaminated by total coliforms, the group of coliform bacteria is applied as a general test of water quality monitoring and it has been applied all around the world to carry out studies on drinking water, aquatic systems contamination, raw wastewater sources of contamination as well as systems of wastewater treatment and recreational waters (Rose \& Grimes, 2001); those reasons explain why these waters cannot be provided to the population without previous treatments, as cited by Hunter et al. (2000), who expose that bacteria, although not generally pathogenic in themselves, are indicative of potentially pathogenic microbes presence and consequently as an index of sanitary insufficiencies in the water source.

Furthermore, small watershed $\mathrm{H}$ wells $12 \mathrm{HB}, 13 \mathrm{HB}, 14 \mathrm{HB}, 15 \mathrm{HB}, 16 \mathrm{HB}, 17 \mathrm{HB}$ under study which present coliforms in a smaller percentage than the small watershed $\mathrm{O}$, it diverges from the latter in two aspects a) the wells are sited in places with low population and lower population pressure as seen in figure 4 , besides b) all of the wells according to their profile have their perforation in basalts, which reduces the possibility of direct entry or due to slow coliforms transfer there is no proliferation in the study area.

The finding of coliforms in wells could be due to its structural deficiency (although it was not the subject of study in this paper), as (Rodríguez, Gauna, Martínez, Acevedo, \& Romero, 2012) mentioned, the finding of coliforms is possibly due to fecal matter contamination that may have come from non-jacketed wells or near surface water tables. Similarly, the presence of total coliforms in deep wells, is due to the rupture of struts or because water is extracted at a lower depth as mentioned by Jawson et. al., (1982)

\section{Conclusions:-}

It was statistically determined the presence of total coliforms during the period of study 2006-2016, therefore, groundwater undergoes microbiological contamination.

It can be emphasized that the most abundant precipitation during the period of study was documented in spring, summer and autumn, which is associated to the greater presence of total coliforms. 


\section{Acknowledgments:-}

The National Council of Sciences and Technologies (CONACYT) of Paraguay funded this research project through grants and the authors recognize the support.

\section{References:-}

1. AECID. (febrero de 23 de 2017). Fondo de Cooperación para Agua y Saneamiento. Obtenido de http://www.fondodelagua.aecid.es/es/fcas/donde-trabaja/paises/paraguay.html

2. Di Rienzo, J. A., Casaneves, F., Balzarini, M. G., González, L., Tablada, M., \& Robledo, C. W. (2017). Software estadístico InfoStat. Estadística y Biometría. (2008). Cordoba, Argentina.

3. ERSSAN. (24 de MAYO de 2017). ERSSAN - ENTE REGULADOR DE SERVICIOS SANITARIOS. Recuperado el 24 de MAYO de 2017, de LEY No 1614/2000: GENERAL DEL MARCO REGULATORIO Y TARIFARIO DEL SERVICIO PUBLICO DE PROVISION DE AGUA POTABLE Y ALCANTARILLADO SANITARIO PARA LA REPUBLICA DEL PARAGUAY: http://www.erssan.gov.py/articulo/12095-ley-n16142000-.html

4. Facultad de Ciencias y Tecnolgias. (2010). Plan egulador, ambiental y participativo para las Colonias Unidas . Diagnótico, Universidad Católica Nuestra Señora de la Asunción-Campus Itapúa, Carrera de Arquitectura. Recuperado el 30 de Marzo de 2017

5. FECOPROD. (15 de MARZO de 2017). FECOPROD. Recuperado el 2017 de MARZO de 2017, de FECOPROD, AGROCLIMATE: http://fecoprod.agroclimate.org/?page_id=133

6. Hunter, C. J. (2000). Fecal bacteria in the waters and upland area in Derbyshire, England: Theinfluence of agricultural land use. J. Environ.

7. Macler, B., \& Merkle, J. (2000). Current knowledge on groundwater microbial pathogens and theircontrol. Hydrogeology Journal, 29-40. Recuperado el 25 de Mayo de 2017

8. MAG. (Febrero de 1995). Geología del Paraguay. Recuperado el 20 de Junio de 2017, de Estudio de reconocimiento de suelos, capacidad de uso de la tierra y propuesta de la Región Oriental del Paraguay (PRUT): http://www.geologiadelparaguay.com/Estudio-de-Reconocimiento-de-Suelos-Regi\%C3\%B3n-Oriental-

Paraguay.pdf

9. METEORED. (2015 de MARZO de 2017). Recuperado el 15 de marzo de 2017, de Histórico del tiempo en Posadas: https://www.meteored.com.ar/tiempo-en_Posadas-America+Sur-Argentina-Misiones-SARP-sactual16911.html

10. OMS. (2006). Organización Mundial de la Salud. Recuperado el 15 de JUNIO de 2017, de Guías para la calidad. Primer apéndice a la tercera edición.: http://www.who.int/water_sanitation_health/dwq/gdwq3_es_fulll_lowsres.pdf

11. PAS-PY. (2012). Agua y Agricultura Cuenca la Cuenca del Arroyo Capiíbary. Asunción.

12. Prüss-Ustün, A. (2014). Burden of disease from inadequate water, sanitation and hygiene in low- and middleincome settings: a retrospective analysis of data from 145 countries. Tropical Medicine \& International Health, 894-905. doi:10.1111/tmi.12329

13. PSAG. (2009). vances en el Conocimiento del Sistema Acuífero Guaraní. Montevideo.

14. Rodríguez, S., Guana, L., Martínez, G., \& Acevedo, H. у. (2012). Relación del nitrato sobre la contaminación bacteriana del agua. Artículo Científico, Terra Latinoamericana, Mexico. Recuperado el 17 de Julio de 2017, de http://www.redalyc.org/articulo.oa?id=57324446002

15. Rose, J. B., \& Grimes, D. J. (2001). Revaluation of microbial water quality: Powerful new tools for detection and risk assessment. A report from the American Academy of Microbiology. Recuperado el 15/6/2017, de https://books.google.com.py/books?id=YMfPyL9Ax5oC\&pg=PA36\&lpg=PA36\&dq=Rose,+J.+B.+and+D.+J.+ Grimes.+2001.\&source=bl\&ots=nEpivby_9V\&sig=q-

Mjlt6KI7Mh6S8FdEDZXv82LKA\&hl=es\&sa=X\&ved=0ahUKEwiKmdKl3rzWAhWJIpAKHZaCCO0Q6AEI NzAF\#v=onepage \&q=Rose $\% 2 C \% 20 \mathrm{~J} . \% 20 \mathrm{~B} . \% 20$ and

16. SAG-PY. (2009). Proyecto para la Protección Ambiental y Desarrollo Sostenible del Sistema Acuífero Guaraní. Técnico, Secretaria del Ambiente, Dirección General de Protección y Conservación.

17. STP. (1 de Febrero de 2015). Secretaría Técnica de Planificación del Desarrollo Económico y Social . Recuperado el 20 de Marzo de 2017, de Agua y saneamiento: http://www.stp.gov.py/pnd/ejesestrategicos/diagnosticos/agua-y-saneamiento/

18. Wada, Y., van Beek, L., van Kempen, C., Reckman, J., Vasak, S., \& Bierkens, M. (2010). Goblal depletion of groundwater reources. Geophysical Research Letters. doi:10.1029/2010GL04 